\title{
The first record of freshwater plesiosaurian from the Middle Jurassic of Gansu, NW China, with its implications to the local palaeobiogeography
}

\author{
Ting Gao, Da-Qing Li ${ }^{*}$ D, Long-Feng Li and Jing-Tao Yang
}

\begin{abstract}
Plesiosaurs are one of the common groups of aquatic reptiles in the Mesozoic, which mainly lived in marine environments. Freshwater plesiosaurs are rare in the world, especially from the Jurassic. The present paper reports the first freshwater plesiosaur, represented by four isolated teeth from the Middle Jurassic fluviolacustrine strata of Qingtujing area, Jinchang City, Gansu Province, Northwest China. These teeth are considered to come from one individual. The comparative analysis of the corresponding relationship between the body and tooth sizes of the known freshwater plesiosaur shows that Jinchang teeth represent a small-sized plesiosaurian. Based on the adaptive radiation of plesiosaurs and the palaeobiogeographical context, we propose a scenario of a river leading to the Meso-Tethys in the Late Middle Jurassic in Jinchang area, which may have provided a channel for the seasonal migration of plesiosaurs.
\end{abstract}

Keywords: Freshwater plesiosaur, Middle Jurassic, Jinchang, Gansu Province, Palaeobiogeography

\section{Introduction}

Plesiosaurs are one of the most familiar groups of Mesozoic marine reptiles, which mainly lived in marine environments. The records of plesiosaurs in non-marine deposits are sparse in comparison to those from marine sediments. Among the known non-marine plesiosaurs, most are from the fluvial and lacustrine sediments (Andrews 1922; Young 1944; Bartholomai 1966; Young 1973; Dong 1980; Zhang 1985; Wu 1987; Xiao et al. 1991; Gao et al. 2004; Sato et al. 2005; Kear 2006; Sato and Wu 2006; Vajda and Raine 2010; Benson et al. 2013; Hornung et al. 2013; Vavrek et al. 2014) and only a few from limnic-brackish lagoon or estuarine deposits (Wiffen et al. 1995; Cruickshank 1997; Cruickshank and Fordyce 2002; Forrest and Oliver 2003; Vandermark et al. 2006; Kear 2007; Kear et al. 2009; Kear and Barrett 2011; Benson et al. 2012; Hampe 2013; Sachs et al. 2016; Sachs et al. 2017). Freshwater plesiosaurs from the Jurassic are even rarer around the world (Thulborn and

\footnotetext{
* Correspondence: daqingli@gsau.edu.cn

Institute of Vertebrate Paleontology and College of Life Science and

Technology, Gansu Agricultural University, Lanzhou 730070, Gansu Province, China
}

Warren 1980; Sato et al. 2003; Kear 2012). Up to now, the taxonomic affinities of most freshwater plesiosaurs have remained unclear; some of them are referred to Plesiosauroidea (Cruickshank and Fordyce 2002; Sato and Wu 2006; Vandermark et al. 2006; Kear et al. 2009; Kear 2012; Vavrek et al. 2014), and the others to Pliosauroidea (Cruickshank 1997; Sato et al. 2003; Kear 2006, 2007; Kear and Barrett 2011; Benson et al. 2012, 2013).

Before this study, all three Chinese genera of freshwater plesiosaurs were attributed to two families of Pliosauroidea; they came from Sichuan (Young 1944; Dong 1980; Gao et al. 2004; Peng et al. 2005), Chongqing (Zhang 1985) and Yunnan (Xiao et al. 1991) in southwestern China and Xinjiang (Young 1973; Wu 1987) in northwestern China. Sinopliosaurus known from Sichuan, Yunnan and Xinjiang was referred to Pliosauridae, while both Bishanopliosaurus and Yuzhoupliosaurus found in Sichuan and Chongqing were referred to the Rhomaleosauridae.

Here we report four teeth of a freshwater plesiosaur from the Middle Jurassic of Qingtujing area, Jinchang 
City, Gansu Province, northwestern China, which were discovered by the field crew of Institute of Vertebrate Paleontology, Gansu Agricultural University (IVPG) in 2017. In this paper, we provide a detailed description of the teeth and discuss their palaeobiogeographical implications.

\section{Geological background}

The study area, Qingtujing, is located in Jinchang City, Gansu Province. The stratigraphic regionalization of this area is attributed to Chaoshui Basin of the North Qilian stratigraphic zone. The Jurassic here is comprised of the Early-Middle Jurassic Qingtujing Group and the Late Jurassic Shazaohe Formation (Fig. 1). The bottom of the Qingtujing Group is missing because of a stratigraphic truncation by a fault, and the top of the Shazaohe Formation contacts the Neogene Baiyanghe Formation with an unconformity. The Qingtujing Group has been divided into two lithostratigraphic units, the Longfengshan Formation and the Xinhe Formation. The Longfengshan Formation is more than $200 \mathrm{~m}$ thick and consists of layers of gray conglomerate and pale-yellow sandstone interbedded with gray-black mudstone, producing petrified woods in the sandstone and Coniopteris hymenophylloides, C. tatungensis and other plant fossils in the mudstone. The Xinhe Formation is about $120 \mathrm{~m}$ in thickness. Its lower part consists of medium-thickbedded layers of straw-yellow conglomerate, sandstone, and siltstone interbedded with greenish-yellow silty mudstone, producing dinosaur remains in its upper sandstone. The upper part of the Xinhe Formation mainly consists of interbeds of bluish-gray shale and mudstone sandwiched with a tuff interlayer, producing a rich lacustrine invertebrate assemblage in the shale including bivalves and conchostracans. The plesiosaurian teeth and some coexistent chelonian remains were collected from a layer of fine conglomerates near the bottom of the upper part of the Xinhe Formation. The Shazaohe Formation is mainly comprised of brown to dark-purple mudstones, muddy siltstones and sandstones, with a thickness greater than $400 \mathrm{~m}$; it has produced no fossils so far in this formation (Fig. 1).

The megafossil plants, palynoflora from the lower part and the lacustrine invertebrate assemblage from the upper part of the Xinhe Formation (Wu et al. 1997; Jiang et al. 2003; Lu 2011; Deng et al. 2016) indicate that the plesiosaur-bearing horizon is of freshwater origin and late Bathonian in age ( $\mathrm{Li}$ et al. 1982; Du 1985; Zhang et al. 2009).

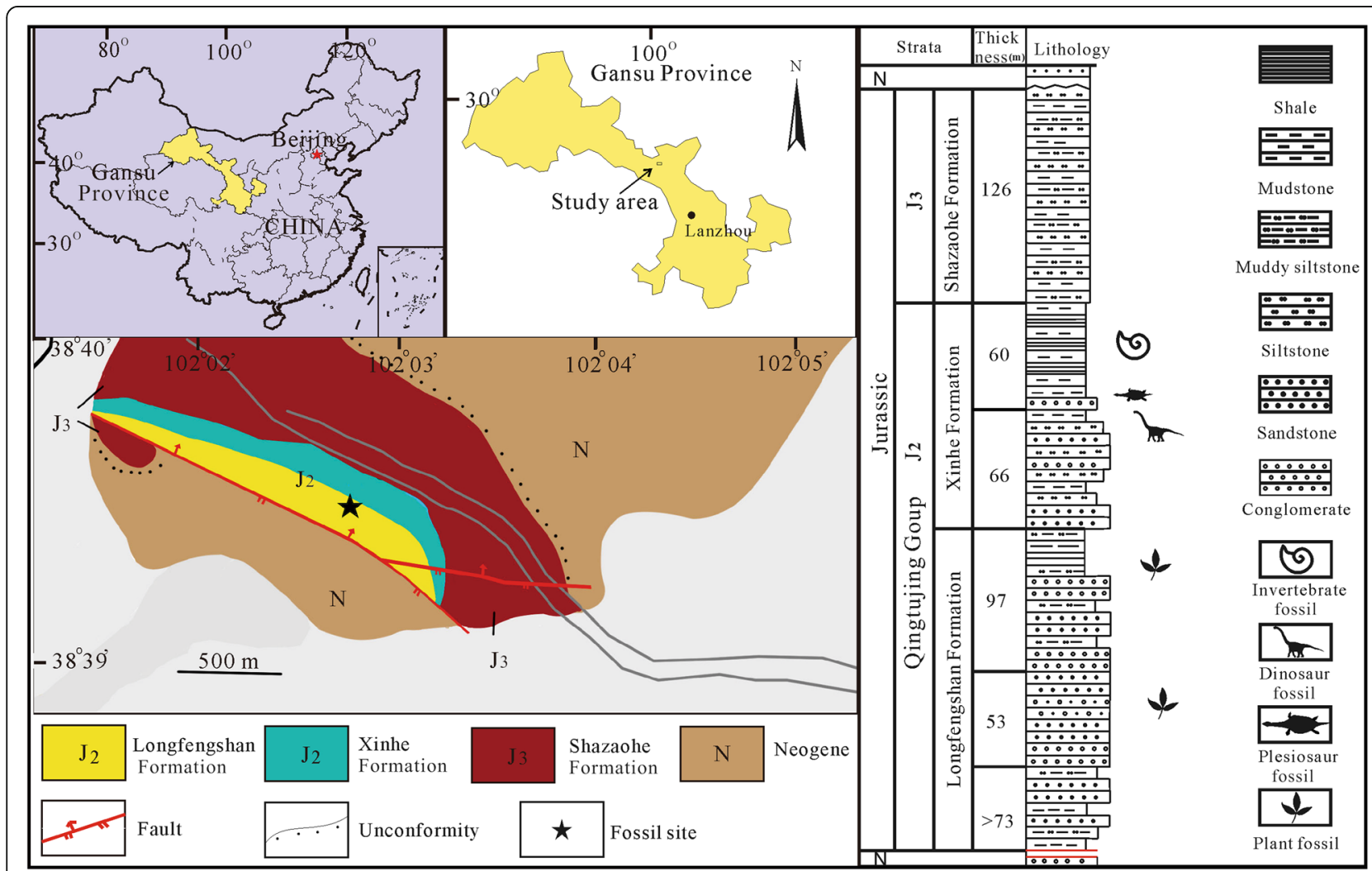

Fig. 1 Geographic and geologic map showing the location and involved strata of the studied fossil site (Inset map of China is modified after State Buteau of Surveying and Mapping, GS (2016)2884) 


\section{Methods}

All of the four teeth were examined under the OLYMPUS SZX10 microscope with the aid of NiKon D5 camera. The figures were prepared by using Adobe Photoshop CS6 and CorelDraw 12.0.

\section{Systematic palaeontology}

Superorder Sauropterygia Owen 1860

Order Plesiosauria de Blainville 1835

Gen. et sp. indet.

\subsection{Materials}

Institute of Vertebrate Paleontology, Gansu Agricultural University, IVPG-S01-S04, four isolated teeth.

\subsection{Locality and horizon}

Qingtujing, Jinchang City, Gansu Province, Northwest China; near the bottom of the upper part of the Xinhe Formation; Middle Jurassic.

\subsection{Description}

The four isolated teeth are most probably from a single individual because they were collected from the same layer of an outcrop (Fig. 2) and they had similar morphology.

IVPG-S01 (Fig. 2a-d) is nearly complete, with slender and slightly curved shape. Its preserved length is about $18.4 \mathrm{~mm}$. The enamel surface of the crown is smooth, with ridges around it from the base to the tip. The cross-section of the crown is round. The root is almost straight, with no ridges on the surface. The crown height is about $9.7 \mathrm{~mm}$, and its basal diameter is about $3.8 \mathrm{~mm}$. The root length is about $8.5 \mathrm{~mm}$, with its diameter about $4 \mathrm{~mm}$, a bit larger than the basal diameter of the crown. The crown stoutness index (the height/basal diameter ratio of the crown) is approximately 2.55 . The ridges on the crown surface are distinct and widely separated from each other. The ridges on the lingual (concave) surface of the crown extend to the tip, while most of those on the labial (convex) surface taper off before reaching the tip.

In general, it is difficult to determine the positions of isolated teeth on the upper and/or lower jaws (Cruickshank and Fordyce 2002; Schumacher et al. 2013), however, there are still some diagnostic features. The posterior teeth are relatively longer than those of the anterior ones (McKean 2012), and the curvatures of the posterior teeth are more pronounced (Taylor and Cruickshank 1993). The root length of IVPG-S01 is relatively short and its crown only slightly curves, so that IVPG-S01 should not be a posterior tooth. In addition, the maxillary teeth of many plesiosaurs are larger than the mandibular ones (Druckenmiller 2002; Smith and Vincent 2010; Benson et al. 2011), while the crown of IVPG-S01 is distinctly smaller than that of IVPG-S02, therefore IVPG-S01 might be a mandibular tooth near the middle region of the jaw.
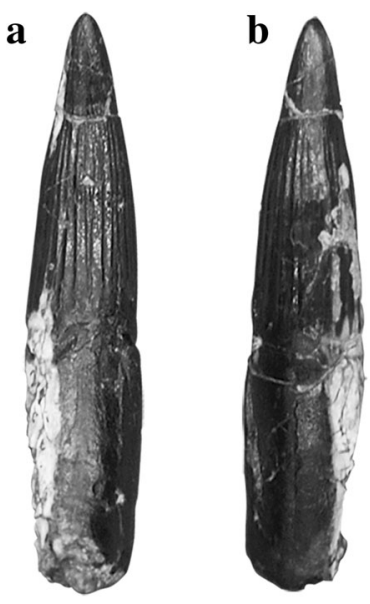

$\mathbf{e}$

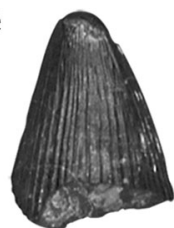

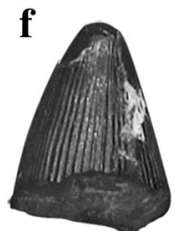
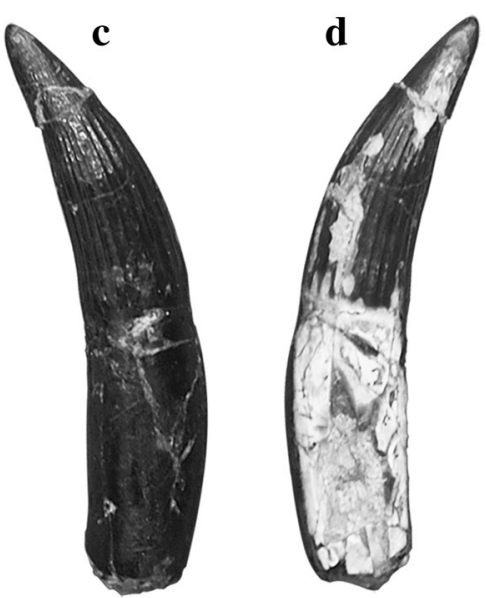

g

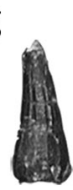

$\mathbf{h}$

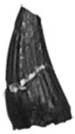

Fig. 2 Plesiosaurian teeth found from Jinchang City, Gansu Province. a Lingual view of IVPG-S01; b Labial view of IVPG-S01, c-d Lateral views of IVPG-S01; e Labial view of IVPG-S02; $\mathbf{f}$ Lateral view of IVPG-S02; $\mathbf{g}$ Lateral view of IVPG-S03; $\mathbf{h}$ Lateral view of IVPG-S04. Scale bars $=10 \mathrm{~mm}$ 
IVPG-S02 (Fig. 2e, f) is a partial crown. The ridges on its surface are clear and extend to the tip. The maximum diameter is $5.1 \mathrm{~mm}$. Compared with the crown stoutness index of IVPG-S01, the crown height of IVPG-S02 might reach $14-22 \mathrm{~mm}$, therefore it might be a maxillary tooth.

IVPG-S03 and IVPG-S04 (Fig. 2g, h) are also partial crowns, which are obviously smaller than IVPG-S01 and IVPG-S02. The preserved lengths are $4 \mathrm{~mm}$ and $4.5 \mathrm{~mm}$ respectively, and the ridges on the surfaces are morphologically comparable to IVPG-S01 and IVPG-S02.

\section{Comparison and discussion}

Due to the vast majority of non-marine plesiosaurian specimens being fragmentary, it is difficult to make comparisons among them. However, the shape and ornamentation of teeth sometimes have a certain diagnostic significance (Tarlo 1960; Brown 1981; Massare 1987; Schumacher et al. 2013; Sassoon et al. 2015).

Compared with the known freshwater pliosauroid materials from China, the teeth of Sinopliosaurus weiyuanensis from the Upper Jurassic of Sichuan and $S$. weiyuanensis from the Lower Cretaceous of Xinjiang, despite their poor preservation, are slightly larger. The teeth of Bishanopliosaurus youngi from the Middle Jurassic of Sichuan are almost complete and very similar to the Jinchang specimens, but they curve more strongly. Yuzhoupliosaurus chengjiangensis from the Middle Jurassic of Chongqing preserved one intact germinated tooth located in the fifth position of the right mandible (Zhang 1985). This tooth differs from the Jinchang specimens in having fine and dense ridges around the crown. It is interesting that the crowns of Jinchang specimens are very similar to those of Sinopliosaurus shezisis (Xiao et al. 1991) from the Upper Triassic of Yunnan, except the root of the latter is unknown.

The teeth of pliosaurids from the Lower Cretaceous of Australia (Kear 2006) differ from the Jinchang specimens in having fine ridges only on the labial surfaces, but other features are similar. The teeth of pliosaurids from the Lower Cretaceous of Australia (Benson et al. 2013) are different from the Jinchang specimens in having irregularly spaced and discontinuous ridges on the crown.

Compared with the known non-marine plesiosauroids, the Late Cretaceous plesiosauroid teeth from the Canadian Arctic have fine longitudinal ridges on the lingual surface, but have no or reduced ridges on the labial surface (Vandermark et al. 2006), while the Jinchang specimens have even and continuous ridges around the crown. The plesiosauroid teeth from the Upper Cretaceous of Alberta, Canada (Sato and Wu 2006) have ridges with different lengths and spacings on the crown, and they do not reach the crown tip, which is similar to the Jinchang specimen in overall shape. In addition, the leptocleidid teeth from the Lower Cretaceous of Germany, South Africa and southern England differ from the Jinchang specimens in having ridges on the lingual surface and having no or few ridges on the labial surface (Cruickshank 1997; Kear and Barrett 2011; Hampe 2013).

The Jinchang teeth are similar to those of some pliosauroid teeth in enamel ridge ornamentation characteristics, including slight curvature, round crosssection, widely spaced ridges (Kear 2006; Ketchum and Benson 2011; Angst and Bardet 2016), and the height/basal diameter ratio of crown varying from 2.0 to 3.0. In Pliosauroidea, the teeth of rhomaleosaurids have relatively simple and uniform shapes, and the crowns have relatively strong curvatures (Dong 1980; Massare 1987; Taylor 1992; Smith and Vincent 2010; Smith and Araujo 2017) (Fig. 3), while the pliosaurid teeth have diverse shapes, and among the teeth of different genera there are few differences. The Jinchang specimens have more even ridge spacings of the crown, but they are similar to Sinopliosaurus, Pachycostasasaurus, Pelenoustes, Liopleurodon in some features such as with distinct ridges around the crown and extending almost to the tip (Noè 2001; Sassoon et al. 2015; Madzia 2016). Therefore, Jinchang specimens may be closer to members of Pliosauridae, but this speculation requires more skull material to verify.

The plesiosaurs occurred in the non-marine environments are typically dominated by small individuals or juveniles (Forrest and Oliver 2003; Sato et al. 2003; Kear 2006; Vandermark et al. 2006; Kear and Barrett 2011; Benson et al. 2012; Hampe 2013; Vavrek et al. 2014; Sachs et al. 2016), but there are also a few records of large ones (Benson et al. 2013; Sachs et al. 2017). Table 1 shows that the crown heights of the individuals with medium to large body size are at least not less than 36 $\mathrm{mm}$, while those of the individuals with small body size range from $4.5 \mathrm{~mm}$ to $54 \mathrm{~mm}$. Although it is inherently uncertain to estimate the body sizes based on isolated teeth, the comparison (Table 1) shows that the Jinchang specimens should come from a small pliosaurid individual.

There are several hypotheses on the occurrences of plesiosaurian remains in non-marine sediments, including that they were forced to seek refuge in a freshwater or inshore environment by survival competition (Andrews 1922; Cruickshank 1997; Kear 2006; Sato and Wu 2006), etc. A popular view considers that there was an adaptive radiation/migration for plesiosaurs because the water temperature and the amount and types of seasonal food changed or in order to survive from competition with different groups in the same habitat (Dong 1980; Sato et al. 2003; Kear 2007; Vavrek et al. 2014). Moreover, 


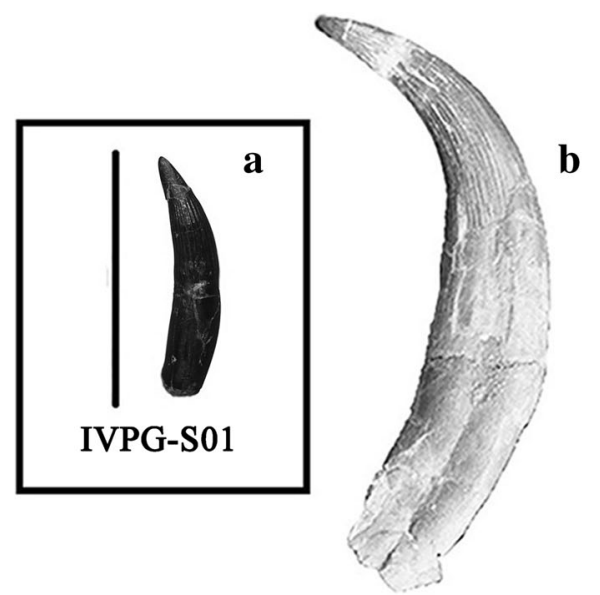

\section{b}

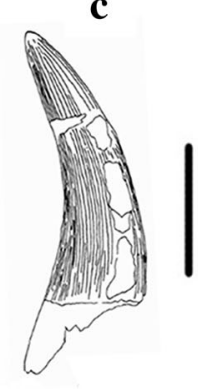

d

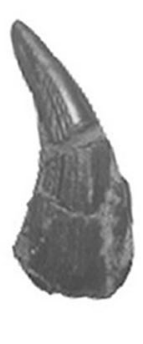

e

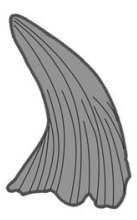

Fig. 3 Tooth comparisons of rhomaleosaurids with IVPG-S01, showing the differences of crown curvature (CC). a Lateral view of IVPG-S01, CC = 1.08; b Lateral view of Bishanopliosaurus youngi (ZDM 40001), from Peng et al. 2005, CC =1.22; c Lateral view of Rhomaleosaurus victor, from Massare 1987, CC =1.15; d Lateral view of Thaumatodracon wiedenrothi, from Smith and Araujo 2017, CC $\approx 1.2$; e Lateral view of Meyerasaurus victor, modified from Smith and Vincent 2010, CC $\approx 1.3$. Scale bars $=20 \mathrm{~mm}$. CC of the two teeth $\mathbf{d}$ and $\mathbf{e}$ are only a rough numerical value, because they do not completely expose the crown

Table 1 Comparisons between body and tooth sizes of freshwater plesiosaurians

\begin{tabular}{|c|c|c|c|c|}
\hline Specimen & Taxon & Tooth size & Body size & Reference \\
\hline IVPG-S01 & $\begin{array}{l}\text { Pliosauridae } \\
\text { Gen. et sp. indet }\end{array}$ & $\begin{array}{l}\mathrm{L} \approx 18.4 \mathrm{~mm} \\
H \approx 9.7 \mathrm{~mm} \\
D \approx 3.8 \mathrm{~mm}\end{array}$ & Small & This study \\
\hline ZDM 4001 & $\begin{array}{l}\text { Pliosauroidea } \\
\text { Gen. et sp. indet }\end{array}$ & $\begin{array}{l}L \approx 70 \mathrm{~mm} \\
H \approx 37 \mathrm{~mm} \\
D \approx 14.8 \mathrm{~mm}(M)\end{array}$ & $\begin{array}{l}\text { Large } \\
\text { About } 4 \mathrm{~m} \text { long }\end{array}$ & Peng et al. 2005 \\
\hline CMN 9454 (two teeth) & $\begin{array}{l}\text { Elasmosauridae } \\
\text { Gen. et sp. indet }\end{array}$ & $\begin{array}{l}\mathrm{L} \approx 9.1 \mathrm{~cm} ; 6.7 \mathrm{~cm} \\
H \approx 30 \mathrm{~mm} ; 25 \mathrm{~mm} \\
D \approx 9 \mathrm{~mm}(M) ; 7 \mathrm{~mm}(\mathrm{M})\end{array}$ & Small & Sato and Wu 2006 \\
\hline NMV P198945 & $\begin{array}{l}\text { Pliosauridae } \\
\text { Gen. et sp. indet }\end{array}$ & $\mathrm{L}>45.1 \mathrm{~mm}$ & $\begin{array}{l}\text { Large } \\
\text { About } 4 \mathrm{~m} \text { long }\end{array}$ & Benson et al. 2013 \\
\hline $\begin{array}{l}\text { NMV P228442 } \\
\text { NMV P212943 }\end{array}$ & $\begin{array}{l}\text { Plesiosauria } \\
\text { Gen. et sp. indet }\end{array}$ & $\begin{array}{l}\mathrm{H} \approx 17.9 \mathrm{~mm} ; 10.8 \mathrm{~mm} \\
\mathrm{D} \approx 7.7 \mathrm{~mm}(\mathrm{M}) ; 4 \mathrm{~mm}(\mathrm{M})\end{array}$ & Small & Benson et al. 2013 \\
\hline Axel Heiberg specimens (two teeth) & $\begin{array}{l}\text { Elasmosauridae } \\
\text { Gen. et sp. indet }\end{array}$ & $\begin{array}{l}\mathrm{H}=12.45 \mathrm{~mm} ; 18.34 \mathrm{~mm} \\
\mathrm{D}=3.61 \mathrm{~mm} ; 3.12 \mathrm{~mm}\end{array}$ & $\begin{array}{l}\text { Small } \\
\text { No more than } 3.9 \mathrm{~m} \text { long }\end{array}$ & Vandermark et al. 2006 \\
\hline $\begin{array}{l}\text { AM F105661 } \\
\text { AM F112844 } \\
\text { AM F121679 } \\
\text { AM F121720 } \\
\text { NMV P186376 } \\
\text { NMV P186416 }\end{array}$ & $\begin{array}{l}\text { Pliosauroidea } \\
\text { Gen. et sp. indet }\end{array}$ & $\mathrm{H} \approx 4.8-53.5 \mathrm{~mm}$ & $\begin{array}{l}\text { Small } \\
\text { About 2-3 m long }\end{array}$ & Kear 2006 \\
\hline QM F4008 & $\begin{array}{l}\text { Plesiosauria } \\
\text { Gen. et sp. indet }\end{array}$ & $\mathrm{H} \approx 37.4 \mathrm{~mm}$ & About 3-4 m long & Kear 2012 \\
\hline SMNS 16812 & $\begin{array}{l}\text { Plesiosauria } \\
\text { Gen. et sp. indet }\end{array}$ & $\mathrm{H} \approx 5-14.7 \mathrm{~mm}(\mathrm{M})$ & Small & O'Keefe 2004 \\
\hline
\end{tabular}

In Peng et al. 2005, the tooth ZDM 4001 belonged to Bishanopliosaurus youngi and placed under Rhomaleosauridae. In Vandermark et al. 2006, the two teeth were called Axel Heiberg specimens, and they have no specimen number

$\mathrm{L}=$ Tooth length; $\mathrm{H}=$ Crown height; $\mathrm{D}=$ Basal diameter of crown; $\mathrm{M}=$ Measured data according to the tooth picture in the original paper

ZDM Zigong Dinosaur Museum; CMN Canadian Museum of Nature; NMV Museum Victoria, Melbourne; AM Australian Museum, Sydney; QM Queensland Museum, Brisbane; SMNS Staatliches Museum für Naturkunde, Stuttgart 


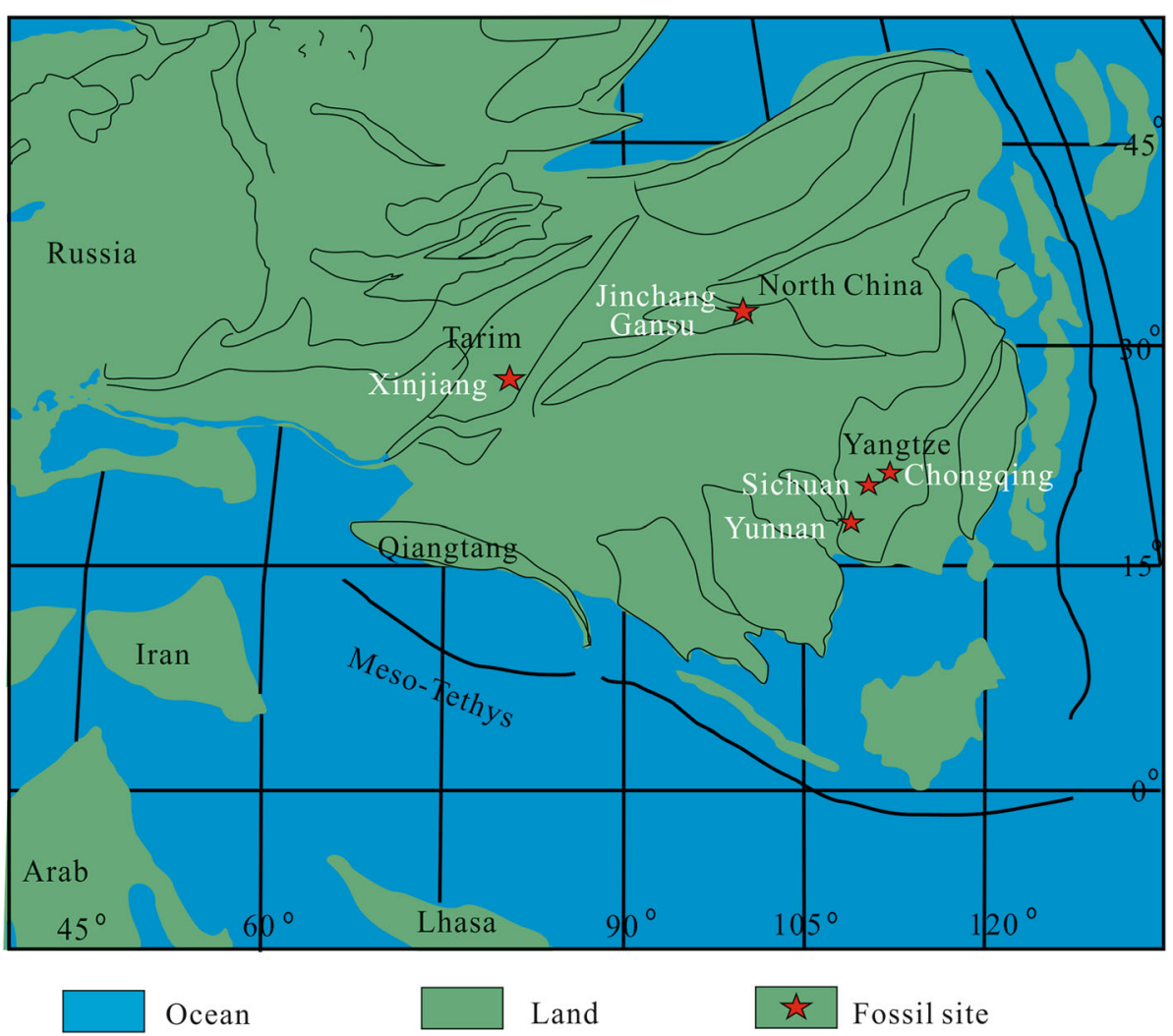

Fig. 4 Schematic diagram of the distribution of the Early-Middle Jurassic plesiosaurs in China. Modified after Hong et al. 2005

plesiosaurs may have had certain habitat preference at different stages of ontogeny, and their juveniles may have had a better adaptability against estuarine or fluviolacustrine environments (Wiffen et al. 1995; Sato and Wu 2006; Benson et al. 2012; Vavrek et al. 2014). So far, most of reported non-marine plesiosaurs are actually juveniles or small individuals, as is also true in China. It is noticeable that the adults and juveniles of the leptocleidid group commonly occurred in freshwater and near shore sediments of the same area in the Cretaceous, and therefore it was speculated that this group could have lived independently in non-marine environments (Russell 1931; Forrest and Oliver 2003; Kear and Barrett 2011; Naish 2013). In addition, the hypothesis that freshwater plesiosaurs can survive independently in freshwater environments also has been proposed in China (Wu 1987).

In the Early to Middle Jurassic, the palaeostructural pattern and palaeogeographical environments of northwestern China were relatively uniform. The mountain ranges, including Tianshan, Qilian and Kunlun Mountains, had become a peneplain by erosion and deplanation in the whole area at that time (Zhao 1998; Liu 2004; Deng et al. 2017; Hu et al. 2017). The EarlyMiddle Jurassic fluviolacustrine sediments are widely distributed on both sides of the Qilian Mountains (including Qaidam Basin in the south and Hexi Corridor Basin and Chaoshui Basin in the north). The MesoTethys Seaway completely retreated to the south of Bayan Har Mountains and widespread marinecontinental and marine deposits occurred in the southwestern part of Tanggula Mountains (Bureau of Geology and Mineral Resources of Qinghai Province 1991). The aforementioned palaeogeographical studies and the work on the evolution of the continental plate movement in China (Hong et al. 2005) suggest that there may have been a channel for the seasonal migration of plesiosaurs from Meso-Tethys to freshwater in Jinchang area during the late Middle Jurassic (Fig. 4).

\section{Conclusions}

The first discovered plesiosaur teeth from the Middle Jurassic freshwater sediments of Jinchang, Gansu should be assigned to Pliosauridae and possibly represent a new taxon. Their occurrence in Jinchang area supports the view that plesiosaurs could migrate seasonally between sea and inland freshwater, and implies that in this area there existed a river leading to Meso-Tethys in the late Middle Jurassic. 


\section{Acknowledgements}

The authors thank Dr. Peter Dodson and Dr. Jun-Chang Lü for providing constructive suggestions on the earlier version of this manuscript. We are deeply saddened by Dr. Lü's early death. We thank He-Ping Duan, Jin-Sen Liang, Wen-Xuan He and Guang-Fu Pan, who joined the fieldwork and prepared the fossils. Special thanks are given to Prof. Guang-Zhao Peng for providing the original picture of Bishanopliosaurus yuungi.

\section{Authors' contributions}

$\mathrm{TG}, \mathrm{D}-\mathrm{QL}$ conceived and designed the experiments. D-QL, TG, J-TY, L-FL performed the experiments. TG, D-QL, J-TY, L-FL analyzed the data. TG, D-QL, J-TY, L-FL contributed reagents/materials/analysis tools. TG, D-QL wrote the paper. All authors read and approved the final manuscript.

\section{Funding}

This study was supported by the Scientific Innovative Fund of Gansu Agricultural University (Grant No. 066-056001).

\section{Availability of data and materials}

The following information was supplied regarding data availability:

The four isolated teeth were discovered by the field crew of the Institute of Vertebrate Paleontology, Gansu Agricultural University (IVPG) in 2017, and were prepared and deposited at IVPG.

\section{Competing interests}

The authors declare that they have no competing interests.

\section{Received: 12 December 2018 Accepted: 30 July 2019 Published online: 13 August 2019}

\section{References}

Andrews, C.W. 1922. Description of a new plesiosaur from the weald clay of Berwick (Sussex). Quarterly Journal of the Geological Society of London 78: 285-295.

Angst, D., and N. Bardet. 2016. A new record of the pliosaur Brachauchenius lucasi Williston, 1903 (Reptilia: Sauropterygia) of Turonian (late cretaceous) age, Morocco. Geological Magazine 153 (3): 449-459.

Bartholomai, A. 1966. The discovery of plesiosaurian remains in freshwater sediments in Queensland. Australian Journal of Science 28: 437-438.

Benson, R.B.J., E.M.G. Fitzgerald, T.H. Rich, and P. Vickers-Rich. 2013. Large freshwater plesiosaurian from the cretaceous (Aptian) of Australia. Alcheringa an Australasian Journal of Palaeontology 37 (4): 456-461.

Benson, R.B.J., H.F. Ketchum, D. Naish, and L.E. Turner. 2012. A new leptocleidid (Sauropterygia, Plesiosauria) from the Vectis formation (early Barremian-early Aptian; early cretaceous) of the Isle of Wight and the evolution of Leptocleididae, a controversial clade. Journal of Systematic Palaeontology 11: 233-250

Benson, R.B.J., H.F. Ketchum, L.F. Noè, and M. Gómez-Pérez. 2011. New information on Hauffiosaurus, (Reptilia, Plesiosauria) based on a new species from the alum shale member (lower Toarcian: Lower Jurassic) of Yorkshire, UK. Palaeontology 54 (3): 547-571.

Brown, D.S. 1981. The English upper Jurassic Plesiosauroidea (Reptilia) and a review of the phylogeny and classification of the Plesiosauria. Bulletin of the British Museum (Natural History). Geology Series 35: 253-347.

Bureau of Geology and Mineral Resources of Qinghai Province. 1991. Regional geology of Qinghai Province, 178-194. Beijing: Geological Publishing House (in Chinese with English abstract).

Cruickshank, A.R.I. 1997. A lower cretaceous pliosauroid from South Africa. Annals. South African Museum 105: 207-226.

Cruickshank, A.R.I, and R.E. Fordyce. 2002. A new marine reptile (Sauropterygia) from New Zealand: Further evidence for a late cretaceous austral radiation of cryptocleidid plesiosaurs. Palaeontology 45: 557-575.

de Blainville, H.M.D. 1835. Description de quelques espèces de reptiles de la Californie, précédée de l'analyse d'un système général d'Erpétologie et d'Amphibiologie. Nouvelles annales du Muséum d'Histoire Naturelle Paris 4: $233-296$.
Deng, S.H., Z.Y. Lu, Y. Zhao, R. Fan, Y.D. Wang, X.J. Yang, X. Li, and B.N. Sun 2017. The Jurassic palaeoclimate regionalization and evolution of China. Earth Science Frontiers 24 (1): 106-142 (in Chinese with English abstract).

Deng, W., Y. Ma, T. Yang, K. Lang, and Y. Li. 2016. Study on source rock characteristics of middle-lower Jurassic in Chaoshui Basin, Gansu Province. Gansu Science and Technology 32 (13): 12-16 (in Chinese with English abstract).

Dong, Z. 1980. A new plesiosauria form the Lias of Sichuan Basin. Vertebrata PalAsiatica 18 (3): 191-197 (in Chinese with English abstract).

Druckenmiller, P.S. 2002. Osteology of a new plesiosaur from the lower cretaceous (Albian) Thermopolis shale of Montana. Journal of Vertebrate Paleontology 22 (1): 29-42.

$\mathrm{Du}, \mathrm{B}$. 1985. Sporo-pollen assemblages from the middle Jurassic in the Wangjiashan Basin of Jingyuan, Gansu, and their stratigraphic and paleogeographic significance. Geological Review 31 (2): 131-141 (in Chinese with English abstract).

Forrest, R., and N. Oliver. 2003. Ichthyosaurs and plesiosaurs from the lower Spilsby sandstone member (upper Jurassic), North Lincolnshire. Proceedings of the Yorkshire Geological Society 54: 269-275.

Gao, Y., Y. Ye, and S. Jiang. 2004. A new species of Bishanopliosaurus from middle Jurassic of Zigong, Sichuan. Vertebrata PalAsiatica 42 (2) 162-165 (in Chinese with English abstract).

Hampe, O. 2013. The forgotten remains of a leptocleidid plesiosaur (Sauropterygia: Plesiosauroidea) from the early cretaceous of Gronau (Münsterland, Westphalia, Germany). Paläontologische Zeitschrift 87 (4): 473-491.

Hong, H., Z. Ma, G. Cheng, and X. Zheng. 2005. Characteristics of fossil continental plate evolution and movement in China. Oil and Gas Journal 26 (1): 23-28 (in Chinese with English abstract).

Hornung, J.J., S. Sachs, and B.P. Kear. 2013. Sauropterygian fossils from the predominantly limnic-brackish Bückeberg formation (Berriasian-early Valanginian, early cretaceous) of northwestern Germany-diversity, distribution, and palaeoecology. In Palaeobiology and Geobiology of Fossil Lagerstätten through Earth History. A joint conference of the "Paläontologische Gesellschaft" and the "Palaeontological Society of China". Abstracts Volume, ed. J. Reitner, Q. Yang, Y. Wang, and M. Reich, 75. Göttingen: Universität Göttingen.

Hu, J., Y. Ma, Z. Wang, Y. Liu, W. Gao, and T. Qian. 2017. Palaeoenvironment and palaeoclimate of the middle to late Jurassic revealed by geochemical records in northern margin of Qaidam Basin. Journal of Palaeogeography 19 (3): 480-490 (in Chinese with English abstract).

Jiang, F., W. Wang, H. Lü, and C. Liu. 2003. Jurassic charophytes from the Qingtujing Group in the Chaoshui Basin, NW China. Acta Palaeontologica Sinica 42 (2): 257-265 (in Chinese with English abstract).

Kear, B.P. 2006. Plesiosaur remains from cretaceous high-latitude non-marine deposits in southeastern Australia. Journal of Vertebrate Paleontology 26 (1): 196-199.

Kear, B.P. 2007. A juvenile pliosauroid plesiosaur (Reptilia, Sauropterygia) from the lower cretaceous of South Australia. Journal of Paleontology 81: 154-162.

Kear, B.P. 2012. A revision of Australia's Jurassic plesiosaurs. Palaeontology 55: 1125-1138.

Kear, B.P., and P.M. Barrett. 2011. Reassessment of the early cretaceous (Barremian) pliosauroid Leptocleidus superstes Andrews, 1922 and other plesiosaur remains from the nonmarine Wealden succession of southern England. Zoological Journal of the Linnean Society 161: 663-691.

Kear, B.P., A.R. Milner, and P.M. Barrett. 2009. Plesiosaurs from the Jurassiccretaceous Purbeck limestone group of southern England. Proceedings of the Geologists' Association 120: 121-125.

Ketchum, H.F., and R.B.J. Benson. 2011. The cranial anatomy and taxonomy of Peloneustes philarchus, (Sauropterygia, Pliosauridae) from the Peterborough member (Callovian, middle Jurassic) of the United Kingdom. Palaeontology 54 (3): 639-665.

Li, B., F. Xu, Q. Ma, H. Pan, S. Wang, and Z. Li. 1982. Middle Jurassic strata of Wangjiashan Basin, Jingyuan, Gansu. Journal of Stratigraphy 6 (1): 33-40 (in Chinese with English abstract). 
Liu, X. 2004. Palaeogeography of the Meso-Cenozoic and crustal tectonic evolution of basin-mountain area in northwestern China. Journal of Palaeogeography 6 (4): 448-458 (in Chinese with English abstract).

Lu, Z. 2011. Paleontology and stratigraphic division of the Jurassic Qingtuojing Group in the Well Yatou 1 in the Yabulai Basin, 167-168. Research Institute of Petroleum Exploration and Development: Chinese Paleontological Society Academic Annual Meeting. Beijing (in Chinese).

Madzia, D. 2016. A reappraisal of Polyptychodon (Plesiosauria) from the cretaceous of England. PeerJ 4 (1): e1998. https://doi.org/10.7717/ peerj.1998.

Massare, J.A. 1987. Tooth morphology and prey preference of Mesozoic marine reptiles. Journal of Vertebrate Paleontology 7 (2): 121-137.

McKean, R.S. 2012. A new species of polycotylid plesiosaur (Reptilia: Sauropterygia) from the lower Turonian of Utah: extending the stratigraphic range of Dolichorhynchops. Cretaceous Research 34 (3): 184-199.

Naish, D. 2013. Plesiosaurs and the repeated invasion of freshwater habitats: late-surviving relicts or evolutionary novelties? Scientific American Blog Network. https://blogs.scientificamerican.com/tetrapod-zoology/ plesiosaurs-invaded-freshwater-habitats/

Noè, L.F. 2001. A taxonomic and functional study of the Callovian (Middle Jurassic) Pliosauroidea (Reptilia, Sauropterygia). University of Derby, UK, Ph. D. Thesis, 182-347.

O'Keefe, F.R. 2004. Preliminary description and phylogenetic position of a new plesiosaur (Reptilia: Sauropterygia) from the Toarcian of Holzmaden, Germany. Journal of Paleontology 78: 973-988.

Owen, R. 1860. On the orders of fossil and recent Reptilia and their distribution in time. Report of the British Association for the Advancement of Science, 153-166.

Peng, G., Y. Ye, Y. Gao, C. Shu, and S. Jiang. 2005. Jurassic dinosaur faunas in Zigong, 45-47. Sichan: Sichuan People's Publishing House (in Chinese with English abstract)

Russell, L.S. 1931. Fresh-water plesiosaurs. The Canadian Field-Naturalist 45: 135-137.

Sachs, S., J.J. Hornung, J.N. Lallensack, and B.P. Kear. 2016. Evidence for a Simolestes-like plesiosaurian from the Berriasian (lower cretaceous) limnic-brackish Bückeberg group of northwestern Germany. In Abstracts volume of the $5^{\text {th }}$ triennial mosasaur meeting - a global perspective on Mesozoic marine amniotes, ed. B.P. Kear, J. Lindgren, and S. Sachs, 35-37. Uppsala: Uppsala University.

Sachs, S., J.J. Hornung, J.N. Lallensack, and B.P. Kear. 2017. First evidence of a large predatory plesiosaurian from the lower cretaceous non-marine 'Wealden facies' deposits of northwestern Germany. Alcheringa an Australasian Journal of Palaeontology 642: 1-8.

Sassoon, J., D. Foffa, and R. Marek. 2015. Dental ontogeny and replacement in Pliosauridae. Royal Society Open Science 2: 150-384.

Sato, T., D.A. Eberth, E.L. Nicholls, and M. Manabe. 2005. Plesiosaurian remains from non-marine to paralic sediments. In Dinosaur Provincial Park, ed. P.J. Currie and E.B. Koppelhus, 648. Bloomington and Indianapolis: Indiana University Press, America.

Sato, T., C. Li, and X.C. Wu. 2003. Restudy of Bishampliosaurus youngi Dong, 1980, a fresh-water plesiosaurian from the Jurassic of Chongqing. Vertebrata PalAsiatica 41 (1): 17-33.

Sato, T., and X.C. Wu. 2006. Review of plesiosaurians (Reptilia: Sauropterygia) from the upper cretaceous horseshoe canyon formation in Alberta, Canada. Paludicola 5: 150-169.

Schumacher, B.A., K. Carpenter, and M.J. Everhart. 2013. A new cretaceous Pliosaurid (Reptilia, Plesiosauria) from the Carlisle shale (middle Turonian) of Russell County, Kansas. Journal of Vertebrate Paleontology 33 (3): 613-628.

Smith, A., and R. Araujo. 2017. Thaumatodracon wiedenrothi, a morphometrically and stratigraphically intermediate new rhomaleosaurid plesiosaurian from the lower Jurassic (Sinemurian) of Lyme Regis. Palaeontographica Abteilung A: Palaeozoology-stratigraphy 308 (4-6): 89-125.

Smith, A.S., and P. Vincent. 2010. A new genus of pliosaur (Reptilia: Sauropterygia) from the lower Jurassic of Holzmaden, Germany. Palaeontology 53 (5): 1049-1063.
Tarlo, L.B. 1960. A review of the upper Jurassic pliosaurs. Bulletin of the British Museum of Natural History, Geology 14: 147-189.

Taylor, M.A. 1992. Functional anatomy of the head of the large aquatic predator Rhomaleosaurus zetlandicus (Plesiosauria, Reptilia) from the Toarcian (lower Jurassic) of Yorkshire, England. Philosophical Transactions of the Royal Society, B: Biological Sciences 335 (1274): 247-280.

Taylor, M.A., and A.R.I. Cruickshank. 1993. A plesiosaur from the Linksfield erratic (Rhaetian, upper Triassic near Elgin, Morayshire). Scottish Journal of Geology 29: 191-196.

Thulborn, R.A., and A. Warren. 1980. Early Jurassic plesiosaurs from Australia. Nature 285 (5762): 224-225.

Vajda, V., and J.I. Raine. 2010. A palynological investigation of plesiosaurbearing rocks from the upper cretaceous Tahora formation, Mangahouanga, New Zealand. Alcheringa 34: 359-374.

Vandermark, D., J.A. Tarduno, and D.B. Brinkman. 2006. Late cretaceous plesiosaur teeth from Axel Heiberg Island, Nunavut, Canada. Arctic 59 (1): 79-82.

Vavrek, M.J., B.C. Wilhelm, E.E. Maxwell, and H.C. Larsson. 2014. Arctic plesiosaurs from the lower cretaceous of Melville Island, Nunavut, Canada. Cretaceous Research 50: 273-281.

Wiffen, J., V. De Buffre'nil, A. De Ricqle's, and J.M. Mazin. 1995. Ontogenetic evolution of bone structure in late cretaceous Plesiosauria from New Zealand. Geobios 28: 625-640.

Wu, S. 1987. The discovery of Plesiosauria and its significance in South Xinjiang. Xinjiang Geology 5 (1): 105-107 (in Chinese with English abstract).

Wu, S.B., Y.B. Bai, and Y.Y. Yang. 1997. The features of braided river deposits of Qingtujing formation, Changshan section in Chaoshui Basin. Journal of Xi'an Shiyou University (Natural Science Edition) 12 (4): 8-11 (in Chinese with English abstract).

Xiao, Y.W., K.H. Chen, and D.B. Cao. 1991. First discovery of Sinopliosaurus from upper Triassic of Central Yunnan. Regional Geology of China 1991 (2): 180-181 (in Chinese with English abstract).

Young, C.C. 1944. On the reptilian remains from Weiyuan, Szechuan, China. Bulletin of the Geological Society of China 24: 187-209 (in Chinese with English abstract).

Young, C.C. 1973. On the plesiosaur from Junggar Basin, Xinjiang, China Xinjiang paleontology inspection report 2. Beijing: Science Press 11: 1317 (in Chinese).

Zhang, H., Z. He, X. Jin, H. Zhang, G. Li, Z. Yang, J. Jia, C. Cao, and Z. Gan. 2009. Sedimentary environments and coal accumulation of the Baojishan-Honghui Basin, eastern Qilian Mountains. Acta Sedimentologica Sinica 27 (4): 622-631 (in Chinese with English abstract).

Zhang, Y. 1985. A new plesiosaur from middle Jurassic of Sichuan Basin Vertebrata PalAsiatica 23 (3): 65-89 (in Chinese with English abstract).

Zhao, Z.X. 1998. Jurassic of Gansu Province. Acta Geologica Gansu 7 (2): 1-40 (in Chinese with English abstract).

\section{Publisher's Note}

Springer Nature remains neutral with regard to jurisdictional claims in published maps and institutional affiliations.

\section{Submit your manuscript to a SpringerOpen ${ }^{\circ}$ journal and benefit from:}

- Convenient online submission

- Rigorous peer review

- Open access: articles freely available online

- High visibility within the field

- Retaining the copyright to your article

Submit your next manuscript at $\boldsymbol{\nabla}$ springeropen.com 